IRA-International Journal of Management \& Social Sciences

ISSN 2455-2267; Vol.03, Issue 03 (2016)

Institute of Research Advances

http://research-advances.org/index.php/RAJMSS

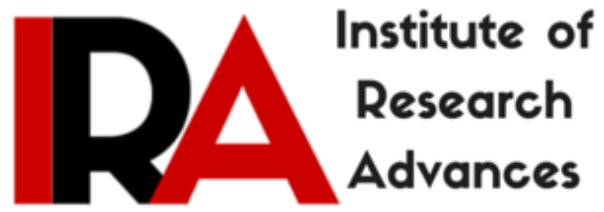

\title{
Sociological Study of Women Domestic Workers in Bangalore City
}

\section{Dr. N. Parameshwara}

Director of Admin,

New Vision Foundation for Safai Karmacharies,

Service, Resource and Research,

\# 63/94, 4th Main, JagajeevanRam Nagara (South) Bengaluru-560018, India.

DOI: http://dx.doi.org/10.21013/jmss.v3.n3.p21

\section{How to cite this paper:}

Parameshwara, N. (2016). Sociological Study of Women Domestic Workers in Bangalore City. IRA-International Journal of Management \& Social Sciences (ISSN 2455-2267), 3(3). doi:http://dx.doi.org/10.21013/jmss.v3.n3.p21

(C) Institute of Research Advances

(cc) EY-NC

This works is licensed under a Creative Commons Attribution-Non Commercial 4.0 International License subject to proper citation to the publication source of the work.

Disclaimer: The scholarly papers as reviewed and published by the Institute of Research Advances (IRA) are the views and opinions of their respective authors and are not the views or opinions of the IRA. The IRA disclaims of any harm or loss caused due to the published content to any party. 


\begin{abstract}
Women in India are approximately about out half of the population, they have been the weakest of the weaker sections which have been the most exploited in every field and in all sectors. Women in have been the most abused and have been undergone a various types of hardships in their everyday life. Even though the government of India have been implemented some of policies implemented as their social security not many of them have come to reality. The women domestic workers in India are the unorganized group who strived to make their living without any life security and are in the vital situations in their social life. Over the last few years, studies on domestic life security in India have noted the increase in the numbers of migrant female domestic workers in the cities. They have also observed that domestic work is highly informal in its organization and tinted the vulnerabilities of domestic workers who belong to the poorer and uneducated sections of society. These studies also note that women from marginalized castes form a substantive group of domestic workers (Kaur 2006; Neetha 2004 and 2008). Domestic workers form a significant part of this informal economy which is unorganised. Despite the fact, domestic workers, constitute a crushing $90 \%$ of this unorganized labor force in India, they have always been marginalized as the unorganised sector. Whether they work part time, full day or as live in workers, they are forced to put up with various indignities, in the privacy of the households they work in. This part of my paper constitutes the study of Domestic workers in the Bangalore city is significant aspect due to its urban development process and women domestic have found to be the most wanted. Domestic workers, an estimated 4 lakhs in Bangalore City work under illogical rules, are largely unskilled and illiterate. For years, women have been doing the drudgery of washing, cleaning, cooking and all menial tasks in other households for their own survival. Long hours of work, years of toil often with no living wage, no rest or recreation, sexual harassment, abuse of their dignity, untouchability, often treated callously are the story of their lives. The conditions of lakhs of child women domestic workers, the 24 hours live in workers, are even more exploitative and obnoxious. There have been many cases of rape and murder, horror tales of children being beaten, locked in bathrooms, bitten and burnt by employers. In my paper I have highlight some of the vital incidents where women have been facing and also the government policies and programmes and polices in the women empowerment in the social sector.
\end{abstract}

This Paper was presented in $37^{\text {th }}$ All India Sociological Conference, Jawaharlal Nehru University, New Delhi, Number and Name of RC: 21 / Social Problems and Marginalized Groups. On $11^{\text {th }}-13^{\text {th }}$ December, 2011.

\title{
INTRODUCTION:
}

Domestic work is not recognized as labour in India. Such workers are generally illiterate and have little awareness of their rights. The exploitation of child labour is beginning to be recognized following regular media coverage, but in general people do not see anything wrong with children working in restaurants, polishing shoes, hawking , or working as domestics. Domestic work in the cities, where the majority of domestic workers are to be found today, has increased greatly over the last 30 years'.

The increase can be attributed to:

1. modernization - has led to more women working out of the home and having to be replaced by domestic workers; 
2. big development projects (darns, mining, deforestation) claiming large amounts of land and thereby forcing entire populations to migrate to the citi.es in order to survive;

3. The reduced involvement of the extended family in caring for children or the elderly.

Domestic workers have always been an 'invisible' work force. Live-in domestics are often even locked up in the house. In a patriarchal society such as India's, cooking, , washing and cleaning have always been left to the women of the house. Since housework has been linked to the lower castes, most domestic workers are poorly paid or underpaid.

$91 \%$ of the 450 million women 111 India works in the 'unorganized sector' in agriculture, as construction workers, as casual laborers and as domestic workers. It is estimated that almost 20 million women, children and men are engaged in domestic work: $92 \%$ of them are women, girls and children $20 \%$ are under the age of 14 and $25 \%$ are between 15 and 20. The arduous struggle of domestic workers in Karnataka for decent wages and working conditions is now 20 years old. Domestic work was included in Karnataka under the Schedule of the Minimum Wages Act in 1992 and then slyly removed in 1993. Fresh struggles ensured its inclusion once more in 2001 and, in a pioneering measure in India; wages were fixed in March 2004. But a Study had done by the SJS (Stree Jagruti sangha) finds that the wages are unnecessarily complex, confusing and inadequate. The minimum wage notification specifies the following for a six-day week: anyone task for 45 minutes per day should receive Rs 249, one hour tasks, Rs 299, and an 8 - hour day Rs 1,699 (all per month) 10\% more for families larger than four persons, and overtime at double the rate.

The study found that the assumptions of 45 minutes per task and a six-day week were incorrect. Due to the varying rates prescribed, it was possible for the employer to calculate the wages in three different ways and arrive at Rs 1,006, Rs 805 and Rs 572 per month as wages for the same two hours of work a day. The SJS study recommends that the minimum wage should be easy to understand, time-based and adequate, and it makes the case for an hourly wage to simplify the calculation.

The study also demands social security and a tripartite board of representatives of the government, employers and workers. This part of my paper constitutes the study of Domestic workers in the Bangalore city is significant aspect due to its urban development process and women domestic have found to be the most wanted. Domestic workers, an estimated 4 lakhs in Bangalore City work under arbitrary rules, are largely unskilled and illiterate.

\section{PROBLEMS OF DOMESTIC WORKERS}

The most frequent problems of domestic workers are long working hours, little or no wages, poor food, lack of personal freedom, no weekly leave, blame for damage or loss of articles - fines and possible criminal charges. Physical and sexual abuse is often part of their life. The newspapers are full of cases of exploitation, discrimination, sexual abuse, unfair treatment, etc. and the greatest abuse done to domestic workers is carried out in the houses $6 f$ those rich enough to live behind closed doors so neighbors do not easily find out what goes on inside. Unless there are grave violations, like scalding with hot water or burning with a hot pressing iron, the media do not' investigate cases abuse of domestic workers thoroughly. Some NGOs try to help domestic workers, but it is very difficult to organize them, especially the child workers. Their' owners' do not allow them to go out or to 'waste time on schooling. They do not want domestic problems to leak out and they do not want the workers to become aware of their rights. 


\section{WORKING CONDITIONS}

All conditions of work for all domestic workers are arbitrary and based on very individual, personalized relationships. Woven into these relationships are personal stories, woman to woman dealings and also factors of loyalty, gratitude, helplessness. They can be broadly classified as part timers, full timers, residential or live in domestic workers. This also includes those working in defense and government quarters. They can also be classified based on the tasks that they do such as those who do only cleaning works, only cooking, childcare or care of the elderly. Very often, these tasks or the division of labour has a caste basis. In most cases, the tasks are not clearly defined by the employer, leading to exploitation. For example, Uma, a domestic worker, says "Apart from the household work, employers make us do extra tasks - cutting vegetables, running errands, looking after the baby, etc. The worst part is that in the end, nothing is recognized. We are only cursed at, blamed and fed with leftovers."

\section{SOCIAL CONDITIONS}

Besides the economic drudgery they face, they also are socially discriminated. Casteist attitudes prevail in many of the employer's houses, where separate glass and plate is kept. They are not allowed to enter the pooja room, nor drink filter water, nor use the toilet, which they themselves clean! This outlook of pollution stems from the fact that most of the workers are from the SC or Dalit community. The practice is. such that in many homes after the worker washes the clothes or vessels, the employer again rinses with drops of water as an act of purification! The domestic worker may work for long hours and yet to be provided with food or tea or coffee. Many of the employers forget that the workers are also humans, have families to take care of, live in deplorable conditions, face health problems, and have the same kind of pressures and problems like them!! Cases of sexual harassment also happen, but many are silent about it and employers ignore and often blame the women. The domestic workers are sometimes treated as criminals, and blamed for any theft in the employer's house. The above plight of domestic workers prevails all over the country, with variations according to region, locality, class and caste' of employers. The domestic workers are also caught in the caste conundrum. There are examples of women following the division of labour very strictly. Some of the women depending on their position in the caste hierarchy do only cooking and not cleaning, while others may do all the cleaning except the toilets, and while there are some who do 'not enter the cooking domain.

\section{OBJECTIVES OF THE STUDY}

* To analysis the socio economic Condition of the Women Domestic Workers

* To understand their occupation structure and wage structure

* To examine their working back ground

\section{SIGNIFICANCE OF THE STUDY}

The middle class and upper middle class family system is heavily dependent on the Domestic Workers so much so that their absence for a day in a house creates a total mess in many families. The Domestic Workers have proved to be a necessity for nonworking housewives also. In urban areas, they commonly engaged domestic workers to keep them in carrying out their household errands, partly due to physical incapability and 
partly due to lack of time. The new middle classes have developed a life style which has increased the demand for domestic workers.

According to the Report on Working Condition of Domestic Servants in Delhi by the Ministry of Labour, Government of India, nearly 90 per cent of domestic workers are women. According to the National Survey conducted by the School of Social Work, women constituted 87.09 \% of Domestic Workers in Karnataka, 82.38 \% in Ranchi, $75 \%$ in Kerala and $90.78 \%$ in Andra Pradesh. The corresponding figures in many of the cities big or small are lacking. The present paper doesn't attempt to identify the numbers of Domestic Workers, (either Full or Part Time) but rather tries to assess the condition of a segment of Domestic Workers i.e. Part Time Domestic Workers whose contribution in the development of the economy of the state has not yet been assessed.

\section{METHODOLOGY}

The study was based on primary data collected from the Domestic Workers (henceforth termed as Domestic Workers) by direct interview. A Questionnaire had been prepared for the purpose for ascertaining various aspects of the Socio - Economic profile of the Domestic Workers inclusive of their willingness for unionization and their socio political attachment with the civil society.

Fifty (50)Women Part Time Domestic Workers were selected from Bengaluru Municipal area from 5 different locations (Anjanappa Garden, Flower Garden, Bhangi Colony, Jaibheem Nagar, Siddhartha Nagar) by purposive sampling method since purposive sampling is a sampling method in which elements are chosen based on purpose of the study. As with other non-probability sampling methods, purposive sampling does not produce a sample that is representative of a larger population.

\section{TOWARDS JUSTICE THROUGH LEGISLATION FOR ALL DOMESTIC WORKERS}

Indian constitution guarantees democracy and confers the right of equality to all strata. But the reality is that this guarantee and fight of equality have not reached many lower sections of society. The case of the domestic workers is evidence to the fact that despite the guaranteed constitutional rights their struggle for equality and survival continues. It is disheartening to note that domestic workers as a part of unorganized work force remain the most exploited ones even after six decades of independence. There is no legislative framework at all in India. The whole outlook on domestic workers is so' feudal here. There are 90 million domestic workers in India, and it's sad there are no rules for them. Across Asia, 'domestic work' (e.g. work carried out in the homes of others) is a common occupation. Yet domestic work is usually not recognized in many societies as $I$ employment' and labour laws do often not protect the workers. Domestic work is not recognized as labour and hence they have no rights such as fixed working hours, weekly offs, medical benefits or paid leave. They are not included in any labour law or Bill.

A Few Acts that do not include domestic workers:

The Workman's Compensation Act of 1923

$>$ The Weekly Holiday Act of 1942

$>$ The provision of Minimum Wages Act of 1948

$>$ The Maternity Benefit Act of 1961

$>$ 111e Personal Injury Act of 1963

$>$ Gratuity Act of 1978 
Through active lobbying, advocacy and campaigning BMS works towards helping domestic workers attain their rights and demand justice for them as workers. We organize awareness programs, advocacy and campaigns, lobbying and consultations for stakeholders with government officials and law enforcement agencies at gram (village), Municipal, state and national levels.

- The Tamil Nadu Government, State of Tamil Nadu, India, included Domestic Workers in their Unorganized Workers Group. The Tamil Nadu Domestic Workers Welfare Board was constituted on the 22nd January 2007. The notification for the Minimum Wage Act for Domestic Workers was passed in August 2007.

- The Central government amended the Central Civil Service Conduct rules to prohibit any government official/civil servants from employing children below the age of 14 years as domestic workers.

- Indian law prohibits the employment of children below 14 years age, in certain occupations in accordance to the Child Labour (Prohibition \& Regulation) Act 1986. By 10th October 2006, the ban on child labour included employment of children in domestic work.

- Karnataka Government's Minimum Wage Act for Domestic workers passed on 1st April 2004 to provide minimum wages to these workers has remained largely on paper.

- Notification for Minimum Wage Act for Domestic Workers was passed in the following State governments: Kerala (23rd May 2005), Andhra Pradesh (24th April 2007) and Rajasthan (4th July 2007).

- The Unorganized Sector Workers' Social Security Bill, 2007 has been passed on 8th January 2008. This Bill also includes domestic workers in the unorganized sector of workers. The Government has enacted the Unorganized Workers' Social Security Act, 2008 for the social security and welfare of unorganized workers which includes domestic workers. The National Social Security Board constituted under the Act has constituted a Sub-Committee of the Board to explore the extension of Social Security Schemes for unorganized workers. The said Sub-Committee recommended domestic workers as one of the categories to be considered for social security.

Accordingly, the Government has set-up a Task Force to evolve a policy frame work for domestic workers in the context of regulatory mechanism and providing social security. The Task Force has been examining various issues such as extending coverage of Rashtriya Swasthya Bima Yojana (RSBY), health and maternity. Benefits, life and disability benefit, old age pension, etc., to domestic workers. It has held three meetings on $13^{\text {th }}$ January, 2010, $1^{\text {st }}$ February, 2010 and $25^{\text {th }}$ February, 2010. The Task Force is likely to submit its Report soon.

- This New Year, the possibility of changing the conditions of work and life of domestic workers came in the form of the Maharashtra Domestic Workers' Welfare Board Bill that was passed by both houses of the legislature during the recently concluded winter session. Although the law has many shortcomings, it is important because it recognizes the rights of these "invisible" workers. 
- Under the provisions of Minimum Wages Act, 1948, both the Central and State Governments can fix/revise minimum wages in the Schedule employment in their respective spheres. Since domestic workers fall under the purview of State sphere, some of the States have included domestic workers as a schedule employment. These States include Andhra Pradesh, Bihar, Karnataka, Rajasthan and Union Territory of Dadra and Nagar Haveli. On the basis of information available, the hourly / daily /monthly rates of wages fixed for domestic workers by these States are as under:

\begin{tabular}{|l|l|l|l|l|l|}
\hline $\begin{array}{l}\text { S1. } \\
\text { No }\end{array}$ & \multicolumn{2}{|c|}{$\begin{array}{l}\text { States/Union } \\
\text { Territories }\end{array}$} & \multicolumn{4}{|c|}{ Minimum Wage (in Rs.) } \\
\hline & State sphere & Per hour & $\begin{array}{l}\text { Per } \\
\text { day } \\
\text { month }\end{array}$ & $\begin{array}{l}\text { Perfective } \\
\text { date }\end{array}$ \\
\hline 1. & Andhra Pradesh & 12.50 & 100.00 & $2,600.00$ & 10.12 .2007 \\
\hline 2. & Bihar & 11.92 & 95.30 & $2,478.00$ & 01.10 .2009 \\
\hline 3. & Karnataka & $\begin{array}{l}9.13 \text { (for } 45 \\
\text { minutes) }\end{array}$ & 97.44 & $2,533.00$ & $01 . .4 .2009$ \\
\hline 4. & Rajasthan & 10.15 & 81.00 & $2,106.00$ & 24.05 .2008 \\
\hline 5. & Dadra \& Nagar Haveli & & 117.80 & - & 25.09 .2007 \\
\hline
\end{tabular}

\section{BEYOND LEGISLATION}

Domestic workers--They sweep, they swab, they wash, they cook, they take care of children and our pets, and they look after our elderly. We see them every day. Yet they are invisible. Yes, millions of women, men and children - India's large force of domestic workers, or 'servants', as most 'people call them - remain unseen, undervalued and denied rights that all workers deserve. This is a subject to which we are forced to return every now and then. Sometimes it is a tragedy that forces us to think. Of course, laws alone cannot deal with a problem that constantly plays hide and seek. For decades, trade unions have been campaigning for recognition of domestic work as a form of labour. Our diligence and persistence has resulted in some States initiating legislation.

$\checkmark$ Both Andhra Pradesh and Karnataka" have included domestic workers in the legal provisions for minimum wage.

$\checkmark$ Tamilnadu has included domestic work in the Manual Labour Act and ill January 2007 set up the Domestic Workers' Welfare Board.

$\checkmark$ Kerala has taken some steps in this direction, as have Bihar and Rajasthan.

$\checkmark$ The Central government has included domestic workers in provisions under the Unorganized Sector Workers' Social Security Act that was passed in January last year.

$\checkmark$ And now Maharashtra has passed its own law.

Most labour laws face the challenge of implementation but amongst the most difficult must surely be the ones linked to domestic work. To begin with, there are no clear statistics of the number of people working as paid labour in people's homes. The estimated number of domestic workers in India is 90 million but this is probably an underestimate as there has been no systematic study to document such workers 
throughout the country. From the data that exists, it is clear that the overwhelming majority of domestic workers are women and girls. There has been considerable documentation of the abuse young girls, in particular, suffer at the hands of their employers.

An estimated $20 \%$ of domestic workers are children below 14 years of age. Under child labour laws, these children should not be employed. Yet those who do employ them get around the law by claiming that they are "looking after" these children when in fact it is the children who look after them, usually with little or no pay. Such child workers slip between the cracks of labour laws as most laws cover workers over the age of 18 .

The researcher according to his area of specialization has analyzed the data collected in the field work. The data collected has been formulated in the form of tables and it has been analyzed likewise hence the data collected during the field work supporting the research work has a great impact on findings in the research. Hence the tables mentioned and analyzed are self explanatory.

The Table 1 is says that Women Domestic workers in the Age Group of starting form 18-56 years, 18-25 year are totally $4 \%$, in the age 26-35 Years are totally 50\%, and in the age group of 36-45 Years are 34\%, in the age group of members 46-55 Years are $6 \%$, and Above 56 in the group of members $4 \%$. The above facts led us to believe that women usually enter this sector usually after marriage to generate income for sustenance of the family.

The Table 2 is says that Thus the bulk of the women are young of which $68 \%$ are married. And $18 \%$ are widowed. Interestingly unmarried women constitute only about 06 $\%$ of the total workforce engaged in the sector.

The Table 3 describes about the literacy rates of the respondents, for which $73.33 \%$ of the respondents are illiterates and $26.67 \%$ are literates and the table illustrates about the education levels of the respondents and it can been seen through the data presented above.

The Table No 4 is says that Apart from the profile of the Women Domestic workers of their religion, it is the caste which plays a very dominant role because maximum of these women's belong to the $\mathrm{Sc} / \mathrm{St}$ Caste which constitute about $70 \%$ and the remaining of $18 \%$ belong to other back ward caste and remaining of $12 \%$ belong to other caste.

The Table No 5 is says that $46 \%$ of the Women work more than 5 hours in rendering their service, while only $34 \%$ work for their own household work for a similar period of time. $15 \%$ serve only 2 houses while $05 \%$ serve 3 or more houses per day.

The Table 6 describes about the $65 \%$ of the women earn less than Rs 750/month , $19 \%$ has a better earning range of Rs 750 - 1000 while a handful of them $16 \%$ earn more in the range of Rs 1000 - 1500 but none has an Income of more than Rs 1500/-

The Table 7 is describes about the Profession of the husbands of domestic workers Daily wages Laborers 30\%, Auto Drivers $40 \%$ others (Mechanics, Carpenters, 
Security Guards, Factory Workers, Vegetable venders, Etc) 22\%, self employed 5\%, Do not work due to illness or disability $3 \%$.

\section{SUGGESTIONS:}

1. Fixing wages to keep pace with other paid work in the informal sector.

2. Providing support service like day meal to all domestic workers irrespective of their nature of work.

3. Providing the workers some degree of flexibility in working hours.

4. Minimizing degree of command over the workers by the employers and imposing acceptable workload to the workers.

5. Building up proper understanding between workers and employers over worker's failure to attend at work.

6. Setting up formal domestic workers unions, which can look after their interests.

7. Providing equitable extra wages for extra workload due to arrival of employer's guests on holidays and festivals.

8. Providing annual incremental benefit to all workers.

9. Providing minimum leave facilities to the workers.

10. Passing out legislations for the welfare of the workers.

\section{CONCLUSION:}

The list of domestic workers is a very long one. They are unprotected workers in the sense that while all the workers are yet to be identified and hence do not get the protection of several legislative provisions. Thus Minimum Wages Act (1948), Equal Remuneration Act (1976), Interstate Migrant workmen Act (1979) Bonded Labour System (Abolition \& Regulation) Act (1970) etc. are all there, but do not cover, all these workers.

Secondly implementation of these Acts is also a very big problem for want of adequate Government machinery. Thirdly even trade unions have not been able to look after these workers, to the extent necessary, through these protective measures. Moreover, domestic workers are facing serious problems in both rural and urban sector. It is not by choice that these people have undertaken the vocation they are engaged in. It is a matter of compulsion that they have to do the jobs that they have undertaken. They are not trained formally or systematically for the jobs but somehow manage to do it because of opportunities to be in the vicinity of sites where such job is done. They get migrated to other places where they can work or get work and face difficulties of shelter etc. They are isolated and scattered and do not even have the social ties to feel secure. Even then, the basic cause of concern here is the non-availability of a continuous job all the year long, not to speak of other aspects of decent work like Environment, Health, and Safety.

\section{BIBLIOGRAPHY:}

* Amar Nath Singh, 2001, "Women domestic workers, socio-economic life", Shipra Publications.

* Kothari, U. 1997. "Women's Paid Domestic Work \& Rural Transformation: A Study of South Gujarat", Economic and Political Weekly, XXXII, 17, 26 April-2 May, pp. WS.5 WS.12.

* Kujur, J.M. \& V.Jha. 2008. Tribal Women Domestic Workers in Delhi, New Delhi: Indian Social Institute. 
* Geeta Menon (2005) "Domestic Workers and Demand for Living Wages" Stree Jagruti Samiti, May-June 2005.

Nirmala Banerjee 1999 "Women in Emerging Labour Market" Indian Journal of Labour Economics, Vol.42 (4).

Jagori, 2008, Rights and Dignity: Women Domestic Workers in India. Info pack

* National Commission on Self Employed Women and Women in the informal Sector, 1998, Shramshakti: report of the Commission. Delhi: Government of India.

* Neetha, N. 2003, 'Migration, Social Networking and Employment: A Study of Domestic Workers in Delhi', NLI Research Studies, No.37, V.V. Giri National Labour Institute, NOIDA.

* Raghuram, Parvati, 2001, 'Castes and gender in the Organization of Paid Domestic Work in India' Work, Employment and Society, Vol. IS, NO.3.

* Banerjee, N., 1982 unorganized women workers: The Calcutta experience, Centre for Studies in Social Sciences, Calcutta.

* Tripathi, S. N. and Das. S, Informal Women Laborer in India. Discovery publishing House, New Delhi. 1991.

* Gangrade, K. D. and Gathia, J. A., Women and Child Workers in Unorganized Sector. Concept Publishing Company, New Delhi. 1983.

* Banerjee Nirmala (1985) 'Women Workers in the Unorganized Sector- The Calcutta Experience' Sangham Book Pvt. Limited, Hyderabad.

Bhatt.Ela (1989); 'Shramshakti Report of the National Commission on Self Employed Women and Women in the Informal Sector'

- Unni Jeemol and Rani Uma (1999) 'Informal Sector Women in the Emerging Labour Market'. The Indian Journal of Labour Economics, Vol-42, No.4

* Srinivasan, Mini 2010. 'Domestic Child Labour: The Dirty Secret of the Rising Middle Class'. Labour File. Volume 8 No. 1-3, January - June 2010, pp. 44- 45.

* Thatte, Medha 2010. 'Pune Domestic Workers on the March'. Labour File. Volume 8 No. 1-3, January - June 2010, pp. 60 - 61. 